\title{
Adoption of mobile applications for teaching-learning process in rural girls' schools in India: an empirical study
}

\author{
Sheshadri Chatterjee ${ }^{1}$ - Dipasree Majumdar ${ }^{2}$. Sanjay Misra ${ }^{3,4}$. \\ Robertas Damaševičius ${ }^{5}$
}

Received: 20 November 2019 / Accepted: 16 March 2020/ Published online: 23 March 2020

(C) The Author(s) 2020

\begin{abstract}
The purpose of this study is to identify the factors that can impact the adoption of mobile apps for teaching-learning process focusing on the girls' school in rural India. The hypotheses were proposed and a conceptual model has been developed. There is a survey work conducted to collect the data from different respondents using a convenience sampling method. The model has been validated statistically through PLS-SEM analysis covering feedbacks of 271 effective respondents. The study highlights the impact of different antecedents of the behavioural intention of the students of using mobile applications for teaching-learning process. The results also show that among other issues, price value has insignificant influence on the intention of the girl students of the rural India. During survey feedbacks have been obtained from the 271 respondents, which is meagre compared to vastness of the population and school of rural India. Only few predictors have been considered leaving possibilities of inclusion of other boundary conditions to enhance the explanative power more than that has been achieved in the proposed model with the explanative power of $81 \%$. The model has provided laudable inputs to the educational policy makers and technology enablers and administrators to understand the impact of the mobile applications on the rural girls' school of India and facilitate the development of m-learning. Very few studies been conducted to explore the impact of mobile applications on the school education of rural India especially focusing on the girls' schools.
\end{abstract}

Keywords Mobile learning · Learning systems · Distance education · Elearning · Technology acceptance

Robertas Damaševičius

robertas.damasevicius@polsl.pl

Extended author information available on the last page of the article 


\section{Introduction}

During last two decades there has been a considerable spurt in the educational field in India (Donnelly and Evans 2019). Some experts opine that this is due to the intervention of private sectors in the school education management. They only, for their financial gain, have presented a show-off as opined by others (Kremer et al. 2013). Hence, for ensuring development in teaching learning process in the ambience of school education, it needs a paradigm shift (Menon et al. 2014). There is a clear need to introduce a new system replacing the older systems of teaching learning process (Hines et al. 2013). To impart good quality of education, a special attention is to be given on some basic issues. It is observed that there is dearth of linkage between theoretical learning and practical applications in the school education level (Tankeleviciene and Damaševičius 2009a). To address the situation, the technology embedded education is required as an alternative solution (Mclaren et al. 2014). In this context, there is possibility of the development of school education standard if the help of smartphones is taken, because this digital technology has become familiar to all (Papadakis et al. 2017). As the mobile devices are portable and usable for the day-today activities of the students, they can be exploited in the education industry as well (Mulatu et al. 2018). Students can be offered personalized learning objects accustomed to their previous learning level and learning style (Burbaite et al. 2014). Especially, young children feel easy to interact with touch screen as like as they feel comfortable to play with the toys (Sharkins et al. 2015).

Mobile application can provide easy handling by the children because a separate keyboard and mouse will not be required here. Studies highlight that todays children feel more comfortable to use touch devices like mobiles (Oliemat et al. 2018). Children are found to spend considerable time in front of screen (Papadakis et al. 2017). In such context, it is crucial to arrange to adopt mobile application in the school education particularly in rural India since in India, a massive number of children are going to schools for acquiring facilities of free and compulsory education.

Currently, digital devices are considered as a part of our culture. The digital devices permeate the school life of children (Zaranis et al. 2013). As such, society demands for digital literacy (Noh 2016). In this background, it appears that the tablets have occupied a commonplace in schools today. These are being used regularly for teaching. World Bank and other funding institutions are taking initiatives to authorise educational policy makers to purchase tablets for school education, this would yield better results (Hamhuis et al. 2020; Nikolopoulou 2020).

It is noted that children would not learn if they do not use befitting technology (Torkar et al. 2018). Smart mobile devices have become a very popular medium for primary education (Zaranis 2016) as well as university education (Ojino and Mich 2018). The students can learn by sharing knowledge through mobile apps with their teachers and among themselves. This, of course, requires sincerity of the child users (Madden et al. 2013). This sincerity is dominant in the girls compared to boys (Hunter et al. 2010). In this scenario, it is noted that in UK during 2014 , in $70 \%$ of primary and secondary schools, tablets have been used by school students (Al-Huneini et al. 2020; Chou and Feng 2019; Lumagbas et al. 2019). Thus, mobile application is expected to develop school education and adoption of mobile application is expected to yield better results in the girls' school than in the boys' school. Hence, it will be cogent to arrange 
adoption of mobile application more and more in the girls' school of rural areas of India (Goodwin 2012) at first. Mobile application in education particularly for girls, as such, is expected to enrich the school education system leading to the establishment of smart classroom infrastructure (Wogu et al. 2019) and support smart education in general (Singh and Miah 2020). This would eventually enrich the community and contribute to the sustainable development of society.

In this study we consider the adoption of mobile applications for improving teaching-learning process in the girls' school in the rural areas. In schools, gender identities are reproduced and performed (Sharkins et al. 2015). In the same situation of advantages or disadvantages, girls appear to be more accommodative compared to boys (Hunter et al. 2010), whereas when discharging obedience, girls are more amiable than boys (Major and Santoro 2013). It is generally seen that boys exhibit, in general, more unruly behaviour than girls (Lemmers-Jansen et al. 2019). In the rural areas, there exists a huge achievement gap between boys and girls. The improvement of the girls' education through technological support is expected to provide the benefits of allinclusive development to the rural India.

Modern technological applications are expected to improve the education system. This education system should be digital, and the students would learn more with ease. Throughout the world, children are using tablets for their studies (Bayles and KnokeStaggs 2013) or informal technology-supported learning (Raziunaite et al. 2018). Cognitive development of students is expected to be improved through mobile technologies. At the same time, the governments are trying to expand education in all levels by the application of technology (Cifuentes 2015). This would help for adoption of mobile applications in education (Arnott et al. 2016). Different studies reveal that learning in school level through technological help like mobile application yields better result than that obtained through traditional process (Hunter et al. 2010). Thus, the adoption of mobile application would derive immense benefit to school education (Remmik and Karm 2012).

However, the adoption and equality of use of novel ICT technologies such as mobile smartphone and applications remains a problem in rural communities even in the advanced countries (Salemink et al. 2017). Now, the principal question is how students' acceptance intention can be aligned towards adoption of mobile application in their school studies?

\section{Overview of related work}

Studies of adoption behaviour circumscribing technology are considered a vital research area in the IT domain (Cheung et al. 2019). Understanding the vital human factors influencing the use of ICT could lead to transformation of education systems in developing countries (Barakabitze et al. 2019). These adoption theories and models depend on sense of Information Science (IS), on psychology as well as on sociology. The researchers usually analyse the factors influencing human behaviour such as the factors influencing student usage of an online learning community (Chinyamurindi et al. 2017). By this way, the researchers ignore contributions of other adoption models or theories. Researchers after choosing a model that fits with the context, usually modify that model through inclusion of some new factors and through exclusion of 
some factors to achieve better results (Dwivedi et al. 2017). The UTAUT model (Venkatesh et al. 2003) is known to have explained $70 \%$ of variability concerning to Behavioural Intention of technology adoption. Other theories or models, on the contrary, can interpret from $17 \%$ to $53 \%$. Besides, we know that most widely used technology adoption model is Technology Acceptance Model (TAM) (Davis 1989).

For example, recently the TAM model has been used to examine the factors influencing the student usage of an online learning community in a rural South African university (Chinyamurindi et al. 2017), to analyse the teachers' perceptions of adopting ICT for teaching at rural secondary schools in South Africa (Chisango et al. 2019), and to examine the feterminants for adopting the mobile apps as learning tools for higher education students in South Africa (Chuchu and Ndoro 2019). TAM and Theory Reason Action was used to analyse the adoption of ICT into teaching based on gender differences in Malaysia (Lim et al. 2019). UTAUT and TAM was used to identify the determinants of the adoption of mobile learning systems among university students in Indonesia (Pramana 2018) as well as to analyse the factors that have an impact on the students' intentions and adoption of m-learning in the higher education institutions of Jordan (Al-Adwan et al. 2018).nThe treatment effects (TE) model was employed to assess the impact of ICT adoption on income diversification of rural households in China (Leng et al. 2020). The adoption of cloud computing based learning resources in underfunded, rural high schools of mainland China was analysed in (Wang and Wong 2019).

\section{Development of hypotheses}

\subsection{Research questions}

We have adopted a holistic attempt to identify the determinants that can impact on the children to intend to behave for acquiring basic school education with the help of mobile applications in rural India so far as girl students are concerned. We have included in our proposed conceptual model, the factors of TAM, factor of UTAUT and other factors like Perceived Risk and Price Value. In this context, the following research questions are to be addressed.

- How applications of mobile would influence the teaching-learning process of the rural girls' school education in India?

- What are the factors that would impact the intention of rural girls' students of India towards adoption of mobile application?

- To what extent, the Behavioural Intention of girls' students of rural India in school level may impact on the adoption of mobile application?

\subsection{Perceived usefulness (PU)}

It is a fact that even in rural India, mobile devices are being used by many people regardless of their age, educational status, financial condition and so on. However, mobile applications in school level education in rural India have yet not been spread to 
the desired extent yet. This is presumably because the users are not aware of its benefits. It is known from research study that adoption rate of an innovative technology would be enhanced if consumers realize its benefit (Cheung et al. 2019). In terms of TAM (Davis 1989), the reason of this is the conception of 'Perceived Usefulness' (PU). It is defined as the conception of the user, that by use of the system, it would derive some benefits. PU is expected to influence Behavioural Intention (BI) of the users to adopt mobile applications (Phua et al. 2012). With these inputs, the following hypothesis is formulated.

H1: Perceived usefulness (PU) significantly and positively impacts the Behavioural Intention (BI) of the users (girls) to use mobile applications in teaching-learning process.

\subsection{Perceived ease of use (PEU)}

The users who would be using mobile application must feel easy to use the technology and then the users would express his/her intention to behave for using this technology. This is called Perceived Ease of Use (PEU). PEU has direct impact on the Behavioural Intention of users (Sathye et al. 2018). Any perceived complexity to use an innovative technology would create impediment to the users. The users then would not exhibit his/her intention to behave for adopting the technology. Studies of TAM and UTAUT highlight that PEU has an effective influence over the intention of the users who would then align to use and adopt the technology (Davis 1989; Venkatesh et al. 2003; Venkatesh et al. 2012). In terms of the above discussions, the following hypothesis is prescribed.

H2: Perceived Ease of Use (PEU) significantly and positively impacts the Behavioural Intention (BI) of the girl students to adopt mobile applications in their teachinglearning process.

\subsection{Perceive risk (PR)}

It is explained as an idea of conviction and of risk. The users apprehend that whenever he/she would use the system or the technology, he/she would face problems and would sustain loss at the stage of outcome (Metag and Marcinkowski 2013). The students would be using mobile apps. This mobile technology is always associated with uncertainty due to its capricious nature. The behavioural insecurity and environmental insecurity would negatively affect the intention of the users to use mobile apps in their studies (Zhang and Maruping 2008). If the Perceived Risks (PR) are decreased, the users of the technology would align to use that technology and his/her adoption behaviour would be enhanced (Hung et al. 2006). The perception of risk has negative effect on the intention. With these perceptions, the following hypothesis is formulated.

H3: Perceived Risk (PR) has a negative impact on the Behavioural Intention (BI) of the girl students towards adopting mobile applications in their teaching-learning process.

\subsection{Effort expectancy (EE)}

This belief is interpreted as an assessment of simplicity in the context of use of a new system (Davis 1989). In the adoption model, it is interpreted that PEU and complexity 
carry the opposite sense. In the field of study concerning technology adoption, EE is considered as a vital and important predictor of Behavioural Intention (BI). This perception has been supported by other studies (Pynoo et al. 2011). These discussions lead to help to develop the following hypothesis.

H4: Effort Expectancy (EE) has a significant and positive impact on the Behavioural Intention (BI) of the girl students of mobile applications in the school level teachinglearning process.

\subsection{Price value}

Price value is interpreted as the money value of the product or the service provided. It is a common experience that whenever the money value of the services or of the products concerned is to be shouldered by the users (here the school students or their guardians), the users' decision towards the adoption is affected (Chong and Chan 2012). The price value appreciably affects the decisions of the consumer in the decision-making mechanisms. The consumers' BI is adversely affected if the user would adopt the technology or not (Kim and Shin 2015). Price value is considered to have negative effect on the BIof the users to use a new technology, that is, in this context, adoption of mobile applications in school study by the girls (Molina-Castillo et al. 2020). It is also noted that so far as an organization is concerned where the users are not scheduled to bear the price value of the new products or the technological costs, it does not affect the BI of the users (Bayles and Knoke-Staggs 2013). In the present context, the organization is the school. The schools are not expected to provide the students with mobiles and to bear the costs of internet service. Naturally, in the present context, Price Value (PR) has negative effect on the consumer BI. With these considerations, the following hypothesis is formulated.

H5: Price Value (PR) has a significant and negative impact on the Behavioural Intention (BI) of the girl students to adopt mobile applications in teaching-learning process.

\subsection{Behavioural intention (BI) and adoption of Mobile application (AMA)}

It is believed that best predictor of individual's behaviour is its intention. BI is considered as a proximal antecedent to action. When an assessment results an effective evaluation, it is seen that the decision is taken for action (Ajzen and Fishbein 2005). Intention is usually interpreted as expression of willingness for attaining the target. Intention predicts behaviour (Conner and Sparks 2015). BI is concerned with the conception of assessing strength of intention of an individual which is instrumental to perform the behaviour (Ajzen and Fishbein 2005). BI may be visualised as a meaningful predictor towards performance of an activity responsive of that intention (Zhang and Guterrez 2007). BI acts as a mediating variable. It impacts to perform a behaviour supporting that activity to which such intention is expressed (Chen and Lu 2011). This intention of students responding favourably to act towards using mobile apps in their studies would help them to behave in favour of Adopting Mobile Application (AMA) in their studies. These discussions have provoked to formulate the following hypothesis. 
H6: Behavioural Intention (BI) of the users will significantly and positively affect the Adoption of Mobile Application (AMA) in rural girls' school of India.

With formulation of these hypotheses, the following conceptual model was developed (Fig. 1).

\section{Research methodology}

\subsection{Preparation of questionnaire}

Since the independent variables are greater in number than dependent variables, for validation, PLS-SEM analysis has been adopted (Abdi 2010). The process involves survey works. A set of questions is to be prepared. These questions (Items) in the form of statements are supplied to some usable respondents. For preparation of questionnaire, we took help of literature studies and have adopted a questionnaire that was previously used for evaluating consumers' adoption of mobile technology (Shukla and Sharma 2018). Other concepts and questions were adopted from other studies as follows: Effort Expectancy and Price Value - from the study on the adoption of ebook technology for reading (Martins et al. 2018), Perceived Risk - from the study on adoption of virtual learning community (Xie 2017). The remaining questions were adopted from the study on mobile wireless technology adoption (Kim and Garrison 2008), from the study on the use a tablet pc for mobile learning (Asunka 2018), and from the study on the factors influencing students' acceptance of m-learning (Abu-AlAish and Love 2013). Eventually, 28 items have been prepared.

The questionnaire was separated into two parts. The first part of the questionnaire contained demographic questions regarding respondent, namely age, gender, location, occupation, and marital status. This part also asked respondents to inform whether they possess a smartphone, use Internet on their mobile, use mobile apps for learning or teaching. One item was used to measure usage of mobile for educational purposes on a

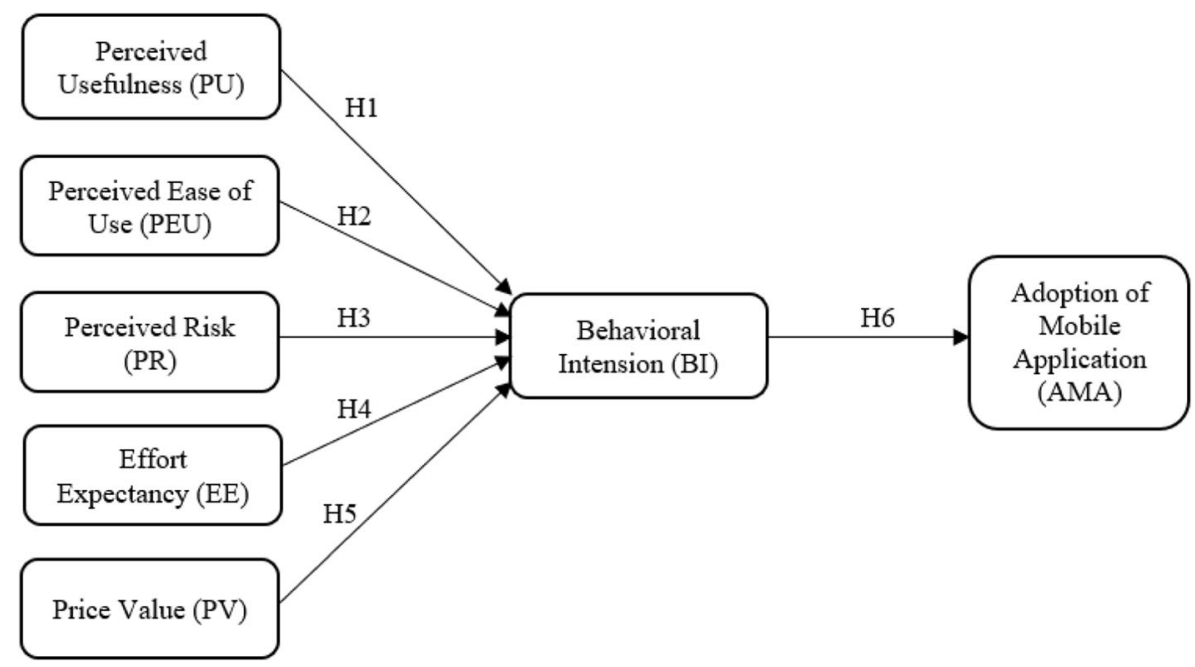

Fig. 1 Conceptual Model 
binary scale of yes or no. Similarly, one item was used to directly measure usage of mobile apps for teaching and learning in yes or no. The second section contained items adapted to measure the constructs of the study (Table 1).

\subsection{Collection of data}

We collected the data from different respondents using the convenience sampling method. For selection of participants, we selected students and teachers of three girls'

Table 1 Questions and constructs of the questionnaire

\begin{tabular}{|c|c|c|c|}
\hline Constructs & Notation & Items & Source \\
\hline \multirow[t]{5}{*}{$\begin{array}{l}\text { Perceived usefulness } \\
\quad(\mathrm{PU})\end{array}$} & PU1 & $\begin{array}{l}\text { I believe that the use of a mobile device would make my } \\
\text { learning/teaching process more effective }\end{array}$ & $\begin{array}{l}\text { Shukla and } \\
\text { Sharma } \\
2018\end{array}$ \\
\hline & PU2 & $\begin{array}{l}\text { I believe that the use of a mobile device would make my } \\
\text { learning/teaching process more convenient }\end{array}$ & $\begin{array}{c}\text { Shukla and } \\
\text { Sharma } \\
2018\end{array}$ \\
\hline & PU3 & $\begin{array}{l}\text { I think that I would save time by using a mobile device } \\
\text { while learning/teaching. }\end{array}$ & $\begin{array}{l}\text { Shukla and } \\
\text { Sharma } \\
2018\end{array}$ \\
\hline & PU4 & $\begin{array}{l}\text { I believe that, in general, using a mobile device in my } \\
\text { learning teaching process would have been useful. }\end{array}$ & $\begin{array}{l}\text { Shukla and } \\
\text { Sharma } \\
2018\end{array}$ \\
\hline & PU5 & $\begin{array}{l}\text { Using mobile apps can improve my learning/teaching } \\
\text { performance. }\end{array}$ & $\begin{array}{l}\text { Kim and } \\
\text { Garrison } \\
2008\end{array}$ \\
\hline \multirow[t]{5}{*}{$\begin{array}{l}\text { Perceived ease of } \\
\quad \text { use (PEU) }\end{array}$} & PEU1 & It is easy to learn/teach using mobile applications. & $\begin{array}{l}\text { Shukla and } \\
\text { Sharma } \\
2018\end{array}$ \\
\hline & PEU2 & $\begin{array}{l}\text { It is easy to learn how to use mobile applications for } \\
\text { learning/teaching. }\end{array}$ & $\begin{array}{c}\text { Shukla and } \\
\text { Sharma } \\
2018\end{array}$ \\
\hline & PEU3 & It is easy to use mobile applications for learning/teaching. & $\begin{array}{l}\text { Shukla and } \\
\text { Sharma } \\
2018\end{array}$ \\
\hline & PEU4 & $\begin{array}{l}\text { I think it would be easy to use a mobile device in my } \\
\text { learning/teaching process. }\end{array}$ & $\begin{array}{l}\text { Shukla and } \\
\text { Sharma } \\
2018\end{array}$ \\
\hline & PEU5 & $\begin{array}{l}\text { It is easy to access online learning/teaching resources } \\
\text { using mobile app. }\end{array}$ & Asunka 2018 \\
\hline \multirow[t]{3}{*}{ Perceived Risk (PR) } & PR1 & $\begin{array}{l}\text { I think that the use of mobile apps for learning/teaching } \\
\text { will lead the leakage and infringement of my privacy }\end{array}$ & Xie 2017 \\
\hline & PR2 & I think the use of mobile apps will be a waste of my time & Xie 2017 \\
\hline & PR3 & I think that mobile app is an inefficient way to learn/teach & Xie 2017 \\
\hline \multirow[t]{5}{*}{$\begin{array}{l}\text { Effort Expectancy } \\
\text { (EE) }\end{array}$} & EE1 & Learning how to use mobile apps is easy for me. & $\underset{2018}{\text { Martins et al. }}$ \\
\hline & EE2 & $\begin{array}{l}\text { My interaction with mobile apps is clear and easy to } \\
\text { understand. }\end{array}$ & $\begin{array}{l}\text { Martins et al. } \\
2018\end{array}$ \\
\hline & EE3 & I consider mobile apps an easy-to-use tool. & $\begin{array}{l}\text { Martins et al. } \\
2018\end{array}$ \\
\hline & EE4 & I find it easy to become proficient with the mobile apps. & $\begin{array}{l}\text { Martins et al. } \\
2018\end{array}$ \\
\hline & EE5 & $\begin{array}{l}\text { Learning to operate a mobile app does not require much } \\
\text { effort. }\end{array}$ & $\begin{array}{l}\text { Abu-Al-Aish } \\
\text { and Love } \\
2013\end{array}$ \\
\hline
\end{tabular}

Price Value (PV) PV1 The pricing of mobile apps is reasonable. 
Table 1 (continued)

\begin{tabular}{|c|c|c|c|}
\hline Constructs & Notation & Items & Source \\
\hline & & & $\underset{2018}{\operatorname{Martins} \text { et al. }}$ \\
\hline & PV2 & $\begin{array}{l}\text { Mobile apps are a good investment compared to the price } \\
\text { paid for them. }\end{array}$ & $\begin{array}{l}\text { Martins et al. } \\
2018\end{array}$ \\
\hline & PV3 & Using mobile apps brings me reasonable price value. & $\underset{2018}{\operatorname{Martins} \text { et al. }}$ \\
\hline \multirow[t]{4}{*}{$\begin{array}{l}\text { Behavioral Intention } \\
\text { (BI) }\end{array}$} & BI1 & $\begin{array}{l}\text { I intend to keep using mobile apps for learning/teaching in } \\
\text { the future }\end{array}$ & $\begin{array}{l}\text { Shukla and } \\
\text { Sharma } \\
2018\end{array}$ \\
\hline & $\mathrm{BI} 2$ & $\begin{array}{l}\text { I intend to increase the use of my mobile apps for } \\
\text { learning/teaching. }\end{array}$ & $\begin{array}{c}\text { Shukla and } \\
\text { Sharma } \\
2018\end{array}$ \\
\hline & $\mathrm{BI} 3$ & $\begin{array}{l}\text { I intend to recommend my friends to using of a mobile app } \\
\text { for learning/teaching in the future. }\end{array}$ & $\begin{array}{l}\text { Shukla and } \\
\text { Sharma } \\
2018\end{array}$ \\
\hline & BI4 & $\begin{array}{l}\text { Assuming I will have access to wireless internet, I intend } \\
\text { to use it. }\end{array}$ & $\begin{array}{l}\text { Kim and } \\
\text { Garrison } \\
2008\end{array}$ \\
\hline \multirow[t]{3}{*}{$\begin{array}{l}\text { Adoption of mobile } \\
\text { application } \\
\text { (AMA) }\end{array}$} & AMA1 & $\begin{array}{l}\text { I believe it would be advantageous to use my mobile } \\
\text { device in my learning/teaching process. }\end{array}$ & $\begin{array}{l}\text { Shukla and } \\
\text { Sharma } \\
2018\end{array}$ \\
\hline & AMA2 & $\begin{array}{l}\text { I think it would be a good idea to use a mobile device } \\
\text { while learning/teaching. }\end{array}$ & $\begin{array}{l}\text { Shukla and } \\
\text { Sharma } \\
2018\end{array}$ \\
\hline & AMA3 & $\begin{array}{l}\text { I think it would be positive to be able to use my mobile } \\
\text { device while learning/teaching. }\end{array}$ & $\begin{array}{l}\text { Shukla and } \\
\text { Sharma } \\
2018\end{array}$ \\
\hline
\end{tabular}

schools (up to Class X) of Malda, a district of West Bengal (a State of India) and some other concerned officials. Total number of prospective respondents were 301 . We took informed consents from the guardians of those students (students are all minors). We also took informed consents of the other respondents. All those 301 prospective respondents were given the 28 questions. They all were requested to provide their feedbacks within one month (September 2018). Within the stipulated period, we received 287 responses. The respondents were given 5 options [Strongly Disagree $(S D)$ to Strongly Agree (SA)] and the respondents were to put tick mark in one option. The options were quantified in 5-point Likert Scale marking SD as 1 to SA as 5. Out of 287 responses, 16 responses were vague and biased as opined by the experts. We did not consider those. We began our work of analysis with 271 usable responses against 28 questions. Our survey works are within the acceptable range as items: respondents lie between 1:4 to 1:10 (Deb and David 2014).

The demographic information of the usable responses is shown in Table 2.

\section{Measurement approach}

\subsection{Computation of LF, AVE, CR, MSV, Cronbach's alpha and VIF}

In validating the questionnaire, we followed the guidelines presented in (Tsang et al. 2017). To test item reliability, Loading Factor (LF) of each item is to be measured. For assessing internal consistency, Composite Reliability (CR) of construct is to be estimated. For testing 
Table 2 Demographic Information of Respondents

\begin{tabular}{lclrr}
\hline Participants & Number & Gender & Number & Percentage (\%) \\
\hline Students & 203 & Girls & 203 & 100 \\
& & Boys & 0 & 0 \\
Teachers & 29 & Female & 26 & 89.6 \\
& & Male & 3 & 10.4 \\
Members of Managing Committee & 18 & Female & 6 & 33.3 \\
& & Male & 12 & 66.7 \\
Government Officials & 21 & Male & 18 & 85.7 \\
& & Female & 3 & 14.3 \\
\hline
\end{tabular}

Convergent Validity, Average Variance Extracted (AVE) of each construct is to be measured, For verifying consistency of constructs and for their validity, Cronbach's alpha $(\alpha)$ and Maximum Shared Variance (MSV) are to be estimated. To test if the constructs' meaning is not very close, Variance Inflation Factor (VIF) of each construct is to be estimated. This defect is known as multicollinearity defect (James et al. 2017). The lowest acceptable values of LF is 0.7.7 (Barroso et al. 2010), of CR is 0.5 (Hair et al. 2018), of AVE is 0.7 (Urbach and Ahlemann 2011), of Cronbach's alpha is 0.6 (Hair et al. 2018). The acceptable range of values of VIF is 3.3 to 5 (Kock and Lynn 2012). Each value of MSV should be less than the corresponding value of AVE. That confirms validity of each construct. All the values have been estimated and are shown in Table 3.

All the estimates are found to be within acceptable range. It confirms the reliability, consistency and validity of the items and of the constructs of the questionnaire.

\subsection{Discriminant validity test}

It is desirable that each item would fully explain its own construct and would weakly explain other constructs. If it is confirmed, the discriminant validity is said to have been established. For this, Average Variance (AV) should be greater than the corresponding correlation coefficients of that construct with other constructs. The values of the parameters are shown in Table 4. AV of each construct shown in diagonal position is greater than the corresponding correlation coefficients shown in off-diagonal positions. It confirms discriminant validity.

\subsection{Structural equation Modelling (SEM)}

With the help of SEM, we can find out the relation among the latent variables. The computation is done using IBM® SPSS $®$ AMOS22. This modelling helps to test if the model so provided is in order or not. It also helps to test whether the structure could represent the date accurately. To achieve this, we have estimated ratio of chi square and degree of freedom. It is 2.021 which is within the acceptable range 0 to $<3$ (Kline 2015). The value of Goodness of Fit Index (GFI) is estimated as 0.909 which is greater than its acceptable lowest value 0.900 (Hoyle 1995). The value of Adjusted Goodness of Fit Index (AGFI) is found to be 0.846 which is greater than its' allowable lowest 
Table 3 Computation of LF, AVE, CR, MSV, $\alpha$ and VIF

\begin{tabular}{|c|c|c|c|c|c|c|}
\hline Constructs/Items & LF & AVE & $\mathrm{CR}$ & MSV & $\alpha$ & VIF \\
\hline Perceived Usefulness (PU) & & .87 & .88 & .24 & .87 & 3.4 \\
\hline PU1 & .92 & & & & & \\
\hline PU2 & .89 & & & & & \\
\hline PU3 & .99 & & & & & \\
\hline PU4 & .96 & & & & & \\
\hline PU5 & .90 & & & & & \\
\hline Perceived Ease of USE (PEU) & & .86 & .89 & .23 & .81 & 3.6 \\
\hline PEU1 & .97 & & & & & \\
\hline PEU2 & .98 & & & & & \\
\hline PEU3 & .90 & & & & & \\
\hline PEU4 & .91 & & & & & \\
\hline PEU5 & .88 & & & & & \\
\hline Perceived Risk (PR) & & .87 & .91 & .22 & .84 & 3.5 \\
\hline PR1 & .99 & & & & & \\
\hline PR2 & .90 & & & & & \\
\hline PR3 & .91 & & & & & \\
\hline Effort Expectancy (EE) & & .87 & .92 & .21 & .87 & 4.9 \\
\hline EE1 & .89 & & & & & \\
\hline EE2 & .93 & & & & & \\
\hline EE3 & .90 & & & & & \\
\hline EE4 & .95 & & & & & \\
\hline EE5 & .99 & & & & & \\
\hline Price Value (PV) & & .87 & .91 & .24 & .82 & 4.2 \\
\hline PV1 & .99 & & & & & \\
\hline PV2 & .90 & & & & & \\
\hline PV3 & .91 & & & & & \\
\hline Behavioral Intention (BI) & & .89 & .93 & .22 & .89 & 4.6 \\
\hline BI1 & .90 & & & & & \\
\hline BI2 & .89 & & & & & \\
\hline $\mathrm{BI} 3$ & .96 & & & & & \\
\hline BI4 & .92 & & & & & \\
\hline Adoption of Mobile Application (AMA) & & .95 & .98 & .24 & .91 & 4.8 \\
\hline AMA1 & .99 & & & & & \\
\hline AMA2 & .98 & & & & & \\
\hline AMA3 & .96 & & & & & \\
\hline
\end{tabular}

value 0.800 (Segars and Grover 1993). Comparative Fit Index (CFI) is estimated as 0.949 which is greater than its' acceptable lowest value 0.930 (Hair et al. 2018). We have also found out Tucker Lewis Index (TLI) which is 0.964. It is greater than its' allowable lowest value 0.950 (Sharma et al. 2005). Root Mean Square Error (RMSE) is estimated as 0.026 which is less than its' permissible highest value 0.070 (Steiger 
Table 4 Discriminant Validity Test

\begin{tabular}{lllllllll}
\hline & PU & PEU & PR & PE & PV & BI & AMA & AVE \\
\hline PU & $\mathbf{. 9 3}$ & & & & & & & .87 \\
PEU & .41 & $\mathbf{9 2}$ & & & & & & .86 \\
PR & .47 & .32 & $\mathbf{. 9 3}$ & & & & & .87 \\
PE & .39 & .31 & .36 & .93 & & & & .87 \\
PV & .42 & .42 & .47 & .39 & .93 & & & .87 \\
BI & .44 & .36 & .44 & .41 & .38 & .94 & & .89 \\
AMA & .49 & .48 & .47 & .46 & .49 & .47 & .97 & .95 \\
\hline
\end{tabular}

2007). Thus, we see that all the parameters are within their respective allowable range. Hence, we can say that the model is in order and it confirms that it has been possible for us to accurately establish the model fit.

\section{Results and findings}

\subsection{Results of the study}

Full results with respect to the coefficient of the determination are shown in Table 5.

With all these inputs, after hypotheses testing and validation through the PLS analysis, the model is shown in Fig. 2.

ns $p>0.05 ; * p<0.05 ; * * p<0.01 ; * * * p<0.001$.

After validation of the conceptual model, the hypothesis H5 has not been supported as the path coefficient is -0.031 with level of significance $p>0.05$ (ns). Other hypotheses have been supported. Behavioural Intention (BI) acting as a mediating variable provides meaningful contribution in explaining the goal (AMA). Power of interpretation can be assessed by the coefficient of determinants $\left(\mathrm{R}^{2}\right)$. All the exogenous variable like PU, PEU, PR, EE and $\mathrm{PV}$ can explain the mediating variable $\mathrm{BI}$ to the tune of $52 \%\left(\mathrm{R}^{2}=0.52\right)$. BI can explain the goal of this study to the tune of $81 \%$. The explanative power of the model is quite high. Out

Table 5 Detail Results including $\mathrm{R}^{2}$

\begin{tabular}{|c|c|c|c|c|c|c|c|}
\hline Effect & Hypothesis & Path & Sign & Path Coefficient & $\begin{array}{l}\text { Significance } \\
\text { Level }\end{array}$ & $\mathrm{R}^{2}$ & Remark \\
\hline Effect on BI & & & & & & 0.52 & \\
\hline by PU & H1 & $\mathrm{PU} \rightarrow \mathrm{BI}$ & + & .32 & $\mathrm{p}<0.05(*)$ & & Supported \\
\hline by PEU & $\mathrm{H} 2$ & $\mathrm{PEU} \rightarrow \mathrm{BI}$ & + & .61 & $\mathrm{p}<0.001(* * *)$ & & Supported \\
\hline by PR & $\mathrm{H} 3$ & $\mathrm{PR} \rightarrow \mathrm{BI}$ & - & .26 & $\mathrm{p}<0.05(*)$ & & Supported \\
\hline by $\mathrm{EE}$ & $\mathrm{H} 4$ & $\mathrm{EE} \rightarrow \mathrm{BI}$ & + & .32 & $\mathrm{p}<0.01(* *)$ & & Supported \\
\hline by PV & H5 & $\mathrm{PV} \rightarrow \mathrm{BI}$ & - & .031 & $\mathrm{p}>0.05(\mathrm{~ns})$ & & Not Supported \\
\hline Effect on AMA & & & & & & 0.81 & \\
\hline by BI & H6 & $\mathrm{BI} \rightarrow \mathrm{AMA}$ & + & .65 & $\mathrm{p}<0.001(* * *)$ & & Supported \\
\hline
\end{tabular}




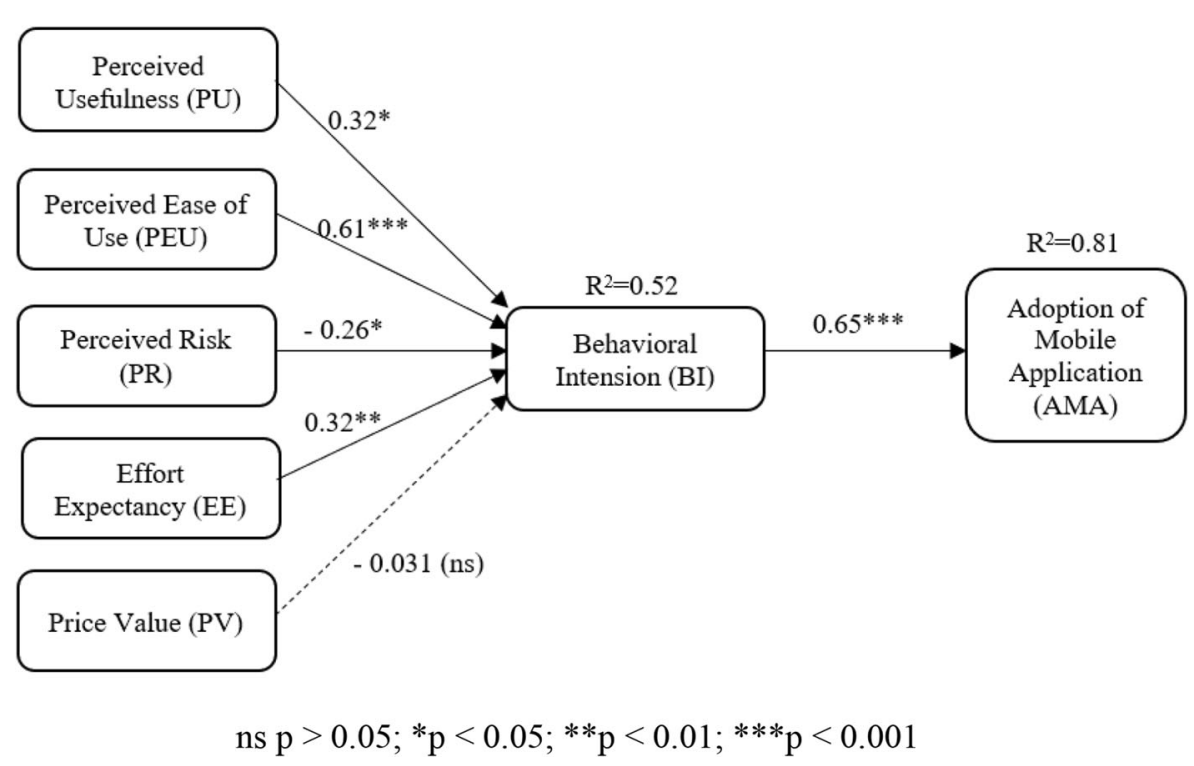

Fig. 2 Structural model with path weights and with level of significance

of the five exogenous variables, it is seen that PEU has the highest impact on $\mathrm{BI}$ as its value is 0.61 . So far as effects of other exogenous antecedents are concerned, the impact of PV on the BI is the lowest. It is -0.031 . This hypothesis (H5) has not been supported. The Perceived Risk (PR) has a negative effect on BI. The concerned path coefficient of this linkage $(\mathrm{PR} \rightarrow \mathrm{BI}, \mathrm{H} 3)$ is -0.26 . The mediating variable $\mathrm{BI}$ has a considerable high impact on the goal of this study, and the concerned path coefficient is 0.65 with significance level $p<0.001(* * *)$.

\subsection{Findings of the study}

After validation through PLS-SEM analysis, the findings of the study are as follows.

- Perceived Usefulness, Perceived Ease of Use and Effort Expectancy have significant and positive impact on the Behavioural Intention.

- Perceived Risk has significant but negative impact on the Behavioural Intention.

- The Price Value has insignificant impact on the Behavioural Intention.

- Behavioural Intention has effective and significant influence on the goal of the study.

- The model is simple but appears to be effective since its explanative power is as high as $81 \%$.

\section{Implication of the study}

\subsection{Theoretical implication}

In this study, we have adopted the elements of UTAUT (Venkatesh et al. 2003) and TAM (Davis 1989). Since, four constructs of UTAUT model do not cover the 
individualistic concept, we also have taken TAM into our consideration. This has been thought to be essential since in this study with others, main stakeholders are the girl students for consideration of adoption of mobile application. That is why PE, PEU and especially BI were considered as essential determinants.

Massification is dominant in rural India as India covers much more rural areas than urban areas (Menon et al. 2014). The inclusion of BI as mediating variable has been essential to analyse the individual behaviour in this context. This idea has also been subscribed by earlier studies (Alshare and Lane 2011). Our proposed model has achieved better result since the explanative power is as high as $81 \%$. We could achieve this probably due to inclusion of better-suited beliefs. It is to note that we have selected some constructs from UTAUT and TAM models and included some other befitting beliefs like PR, PV, BI. This may be considered as a special theoretical contribution of our study. No explicit studies have been so far conducted in this issue. As such, this model will be helpful in this context. Trust is considered as an important factor for analysis of adoption behaviour. In this perspective, we ought to have considered the construct of trust. We have considered Perceived Risk (PR) as an exogenous construct instead. Risk taking may be construed to be identical with trust (Ross Ross and LaCroix 1996). Hence, consideration of PR as one of the variables can be considered as a special theoretical contribution in this study.

We have not deemed it essential to consider the four moderators of the UTAUT model. These moderators would not produce any laudable effects in the field of our study. Without considering these moderators, we could achieve $81 \%$ explanative power which is appreciably high.

\subsection{Practical implication}

In this article, we have strived to investigate how mobile applications in the girls' school in rural India helps to improve the school education system. We have developed a model with a high explanative power $(81 \%)$. Study of the model highlights that Perceived Ease of Use has maximum impact on the Behavioural Intention of the users for adopting mobile application. The designers and developers of mobile apps congenial for studies in school level should design the apps in such a fashion that the users may feel easy to use those. Impact of Perceived Usefulness on Behavioural Intention is also considerable as it comes out from the study. The users of the mobile apps should be made aware about the usefulness of the apps in their studies. For this, the girl students' awareness in this context is to be enhanced. This can be achieved by keeping the users apprised regarding the success stories of the contribution of mobile apps in school studies.

The model also shows that Perceived Risk has negative contribution on the Behavioural Intention. This implies that the authority should keep the girl students aware regarding the risks involved in using the mobile apps in their studies. The result also shows that Perceived Value has insignificant effect on Behavioural Intention. This is presumably because the result has been arrived at by mostly having feedbacks of minor girl students. They are naturally not aware regarding the problems of cost. However, the authority should make the girl students aware for not using the apps unnecessarily. This step might give some financial relief to the concerned guardians. This model is simple and would help the girl students of rural India motivated to adopt mobile apps in their school studies. 


\subsection{Implication for policymakers and stakeholders}

The results of the study also can be used by the policymakers in the area of education management. The mobile apps can be effectively used to provide the opportunities for implementing the e-learning based schooling in remote rural areas, which would enable to deliver high quality educational courses and learning objects in the STEM (Science, Technology, Engineering and Mathematics) areas such as computer science and engineering (Tankelevičiene and Damaševičius 2009b; Štuikys et al. 2017; Costea et al. 2019) at a relatively low cost so that the digital divide between rural and urban schools, as well as between the provinces with a differing level of economical development could be effectively bridged. Based on the results of this study we recommend that the responsible policymakers should ensure that infrastructures necessary for the use of mobile applications are adequate in schools to encourage distance learning and $\mathrm{m}$ learning. Schools and other stakeholders should make their best effort to ensure that electricity supply and wireless internet connections are permanently available. The training of teachers for increasing their proficiency in using educational mobile apps should be implemented.

\subsection{Limitation of study and direction for future research}

The limitations of the study are as follows.

- We have conducted our survey works with the feedbacks from the stakeholders, especially, including the rural girl students of India, who are not adopters of mobile applications, yet. Hence, we have taken feedbacks from the non-adopters. Hence, due attention to be given when this result would be applied to the adopters in appropriate time.

- We have included some factors in this model. We might have included other boundary conditions like image, output expectancy and so on. Future researchers may think of such inclusion and to check, if the explanative power can be increased.

- In the survey works, we considered 271 usable respondents. In comparison to the vastness of rural India, this number is meagre. It should not be considered to represent a general picture. For rendering a generic result, more responses ought to have been considered.

\section{Concluding remarks}

The mobile applications have explored a new possibility to upgrade the rural school education of India. It is expected that when it will be acted upon, the development of school education in rural India will achieve success. When girl students of school level in rural India would use mobile technology, it will also improve the standard of education in their house.

In this study we have provided a comprehensive model for technology acceptance of mobile applications for learning/teaching. It is expected that appropriate use of this model would bring in the overall improvement in the standard of school education in rural India. However, education is principally considered as a human-based endeavour. Full 
dependence on the technological development would never bring in the expected output. The technological advancement can hardly identify the problems. However, to identify these, humans might need the use and application of technology. In this juncture, the help of mobile application might harness meaningful results. Thus, human efforts and technological solution should stand intimately sidewise for nurturing rural school education in India. If rural school education through the girls is improved, this will not only improve the overall health of the rural community but also would spread to the urban areas. This would fetch societal development from all aspects. Both human efforts and use of technology are necessary to stand side by side to ensure the long term and sustainable development in the education sector in India. In brief, it is concluded that:

- This technological use in school-level education, especially to girls in rural India, would fetch appreciable development in the school education.

- Usefulness, ease of use, less complexity of the system and protection of security and privacy would impact significantly on the intention of the stakeholders to use this innovative technology.

- Behavioural Intention of the girl students of rural India would impact a lot on the adoption of mobile application in their studies.

Open Access This article is licensed under a Creative Commons Attribution 4.0 International License, which permits use, sharing, adaptation, distribution and reproduction in any medium or format, as long as you give appropriate credit to the original author(s) and the source, provide a link to the Creative Commons licence, and indicate if changes were made. The images or other third party material in this article are included in the article's Creative Commons licence, unless indicated otherwise in a credit line to the material. If material is not included in the article's Creative Commons licence and your intended use is not permitted by statutory regulation or exceeds the permitted use, you will need to obtain permission directly from the copyright holder. To view a copy of this licence, visit http://creativecommons.org/licenses/by/4.0/.

\section{References}

Abdi, H. (2010). Partial least squares regression and projection on latent structure regression (PLSRegression). WIREs Computational Statistics, 2(1), 97-106. https://doi.org/10.1002/wics.51.

Abu-Al-Aish, A., \& Love, S. (2013). Factors influencing students' acceptance of m-learning: An investigation in higher education. The international review of research in open and distributed learning, 14(5). Doi: https://doi.org/10.19173/irrodl.v14i5.1631.

Ajzen, I. and Fishbein, M. (2005), The influence of attitudes on behavior in. D. Albarracin, B. Johnson, and M. Zanna (eds.). Handbook of attitudes and behavior.

Al-Adwan, A. S., Al-Madadha, A., \& Zvirzdinaite, Z. (2018). Modeling students' readiness to adopt mobile learning in higher education: An empirical study. International Review of Research in Open and Distance Learning, 19(1), 221-241. https://doi.org/10.19173/irrodl.v19i1.3256.

Al-Huneini, H., Walker, S. A., \& Badger, R. (2020). Introducing tablet computers to a rural primary school: An activity theory case study. Computers in Education, 143. https://doi.org/10.1016/j. compedu.2019.103648.

Alshare, K. A., \& Lane, P. L. (2011). Predicting student-perceived learning outcomes and satisfaction in ERP courses: an empirical investigation. Communications of the Association for Information Systems, 28(1), $572 \mathrm{e} 584$.

Arnott, L., Grogan, D., \& Duncan, P. (2016). Lessons from using iPads to understand young children's creativity. Contemporary Issues in Early Childhood, 17(2), 157-173. https://doi.org/10.1177 /1463949116633347. 
Asunka, S. (2018). Instructor perceptions and intentions to use a tablet PC for Mobile learning in a Ghanaian University. In handbook of research on Mobile devices and applications in higher education settings (pp. 495-517). IGI global. doi:https://doi.org/10.4018/978-1-5225-0256-2.ch021.

Barakabitze, A. A., William-Andey Lazaro, A., Ainea, N., Mkwizu, M. H., Maziku, H., Matofali, A. X., \& Sanga, C. (2019). Transforming african education systems in science, technology, engineering, and mathematics (STEM) using ICTs: Challenges and opportunities. Education Research International, 2019. https://doi.org/10.1155/2019/6946809.

Bayles, J., \& Knoke-Staggs, G. (2013). Tablets and children: intuitive technology and new literacies. Tennessee Libraries, 63(2), 1.

Barroso, C., Cepeda, G., \& Roldan, J. (2010). Handbook of partial least squares. In V. Esposito Vinzi, W.W. Chin, J. Henseler \& H. Wang (Eds.), Handbook of partial least squares. Berlin, Heidelberg: Springer.

Burbaite, R., Bespalova, K., Damaševičius, R., \& Štuikys, V. (2014). Context-aware generative learning objects for teaching computer science. International Journal of Engineering Education, 30, 929-936.

Chen, M. F., \& Lu, M. T. Y. (2011). Modelling e-coupon proneness as a mediator in the extended TPB model to predict consumers' usage intentions. Internet Research, 21(5), 508-526. https://doi.org/10.1108 $/ 10662241111176344$.

Cheung, M. L., Chau, K. Y., Lam, M. H. S., Tse, G., Ho, K. Y., Flint, S. W., Broom, D. R., Tso, E. K. H., \& Lee, K. Y. (2019). Examining consumers' adoption of wearable healthcare technology: The role of health attributes. International Journal of Environmental Research and Public Health, 16, 2257. https://doi. org/10.3390/ijerph16132257.

Chinyamurindi, W. T., Mahembe, B., Chimucheka, T., \& Rungani, E. (2017). Factors influencing student usage of an online learning community: The case of a rural south african university. International Journal of Education Economics and Development, 8(2-3), 116-132. https://doi.org/10.1504 /IJEED.2017.086509.

Chisango, G., Marongwe, N., Mtsi, N., \& Matyedi, T. E. (2019). Teachers' perceptions of adopting information and communication technologies in teaching and learning at rural secondary schools in eastern cape, South Africa. Africa Education Review. https://doi.org/10.1080/18146627.2018.1491317.

Chong, A. Y.-L., \& Chan, F. T. (2012). Structural equation modeling for multi-stage analysis on radio frequency identification (RFID) diffusion in the health care industry. Expert Systems with Applications, 39(10), 8645-8654. https://doi.org/10.1016/j.eswa.2012.01.201.

Chou, P.-N., \& Feng, S.-T. (2019). Using a tablet computer application to advance high school students' laboratory learning experiences: a focus on electrical engineering education. Sustainability (Switzerland), 11(2). https://doi.org/10.3390/su11020381.

Chuchu, T., \& Ndoro, T. (2019). An examination of the determinants of the adoption of mobile applications as learning tools for higher education students. International Journal of Interactive Mobile Technologies, 13(3), 53-67. https://doi.org/10.3991/ijim.v13i03.10195.

Cifuentes, G. (2015). Educational governance and innovation: Technology as end and means of government. Policy Futures in Education, 14(2), 286-299. https://doi.org/10.1177/1478210315622916.

Conner, M. and Sparks, P. (2015), Theory of Planned Behavior and Health Behavior in. M. Cooner and P. Sparks (eds), prediction health behavior: Research and practice with social cognition models. 3rd edition. Open University Press. 170-222.

Costea, F.-M., Chirila, C.-B., \& Cretu, V.-I. (2019). Designing E-learning content using AGLOs. In 23rd international conference on system theory, control and computing, ICSTCC 2019, art. No. 8885794, pp. 685-690. DOI: https://doi.org/10.1109/ICSTCC.2019.8885794.

Davis, F. D. (1989). Perceived usefulness, perceived ease of use and user acceptance of information technology. MIS Quarterly, 13(3), 319-340.

Deb, M., \& David, E. L. (2014). An empirical examination of customers' adoption of m-banking in India. Journal of Marketing Intelligence \& Planning, 32(4), 475-494. https://doi.org/10.1108/MIP-07-2013-0119.

Donnelly, M., \& Evans, C. (2019). A 'home-international' comparative analysis of widening participation in UK higher education. Higher Education: The International Journal of Higher Education Research, 77, 97-114. https://doi.org/10.1007/s10734-018-0260-3.

Dwivedi, Y. K., Rana, N. P., Janssen, M., Lal, B., Williams, M. D., \& Clement, M. (2017). An empirical validation of a unified model of electronic government adoption (UMEGA). Government Information Quarterly, 34(2), 211-230. https://doi.org/10.1016/j.giq.2017.03.001.

Goodwin, K. (2012). Use of tablet technology in the classroom. Sydney: NSW Department of Education and Communities.

Hair, J. F., Black, W. C., Babin, B. J., \& Anderson, R. E. (2018). Multivariate data analysis (8th ed.). London: Cengage Learning EMEA. 
Hamhuis, E., Glas, C., \& Meelissen, M. (2020). Tablet assessment in primary education: Are there performance differences between TIMSS' paper-and-pencil test and tablet test among dutch grade-four students? British Journal of Educational Technology. https://doi.org/10.1111/bjet.12914.

Hines, P., Mervis, J., Mecartney, M., \& Wible, W. (2013). Plenty of challenges for all. Sciences, 340(6130), 290-291. https://doi.org/10.1126/science.340.6130.290.

Hoyle, R.H. (1995), The structural equation modelling approach: Basic concepts and fundamental issues, and applications. Thousand oaks, CA: Sage Publication. 1-15.

Hung, S. Y., Chang, C. M., \& Yu, T. (2006). Determinants of user acceptance of the e-government services: The case of online tax filing and payment system. Government Information Quarterly, 23(1), 97-122. https://doi.org/10.1016/j.giq.2005.11.005.

Hunter, J. D., Vickery, J., \& Smyth, R. (2010). Enhancing learning outcomes through group work in an internationalised undergraduate business education context. Journal of Management \& Organization, 6(5), 700-714. https://doi.org/10.1017/S1833367200001814.

James, G., Witten, D., Hastie, T. and Tibshirani, R. (2017), An introduction to statistical learning, Springer Science Publication, New York (8th edition). ISBN 978-1-4614-7138-7.

Kim, S., \& Garrison, G. (2008). Investigating mobile wireless technology adoption: An extension of the technology acceptance model. Information Systems Frontiers, 11(3), 323-333. https://doi.org/10.1007 /s10796-008-9073-8.

Kim, K. J., \& Shin, D. H. (2015). An acceptance model for smart watches: Implications for the adoption of future wearable technology. Internet Research, 25(4), 527-554. https://doi.org/10.1108/IntR-05-2014-0126.

Kline, R. B. (2015). Principles and practice of structural equation Modelling (4th ed.). New York: Guilford.

Kock, N., \& Lynn, G.S. (2012). Lateral collinearity and misleading results in variance-based SEM: An illustration and recommendations. Journal of the Association for Information Systems, 13(7), 546-580.

Kremer, M., Brannen, C., \& Glennerster, R. (2013). The challenges of education and learning in the developing world. Science, 340(6130), 297-300.

Lemmers-Jansen, I. L. J., Fett, A.-K. J., Shergill, S. S., van Kesteren, M. T. R., \& Krabbendam, L. (2019). Girls-boys: An investigation of gender differences in the behavioral and neural mechanisms of trust and reciprocity in adolescence. Frontiers in Human Neuroscience, 13. https://doi.org/10.3389 /fnhum.2019.00257.

Leng, C., Ma, W., Tang, J., \& Zhu, Z. (2020). ICT adoption and income diversification among rural households in China. Applied Economics. https://doi.org/10.1080/00036846.2020.1715338.

Lim, S. C., Lim, S. P., Lee, C. K., Yiung, S. N., \& Isawasan, P. (2019). An empirical investigation on adoption of ICT into teaching based on gender differences. Journal of Advanced Research in Dynamical and Control Systems, 11(8), 1147-1156.

Lumagbas, J. J., Smith, W., Care, E., \& Scoular, C. (2019). Tablet computers in philippine public schools: School-level factors that influence technology management and use. Technology, Pedagogy and Education, 28(1), 73-89. https://doi.org/10.1080/1475939X.2019.1572535.

Madden, M., Lenhart, A., Duggan, M., Cortesi, S., \& Gasser, U. (2013). Teens and technology 2013. Washington, DC: Pew Internet \& American Life Project.

Major, J., \& Santoro, N. (2013). "Sensible girls" and "silly boys": What do teachers need to know about gender? The Australian Educational Researcher, 41(1), 59-72. https://doi.org/10.1007/s13384-013-0121-0.

Martins, M., Farias, J., Albuquerque, P. H., \& Pereira, D. (2018). Adoption of Technology for Reading Purposes: A study of E-books acceptance. Brazilian Business Review, 15(6), 568-588. https://doi. org/10.15728/bbr.2018.15.6.4.

Mclaren, S. V. (2014). STEM: natural partners project-learning for sustainability. In STEM and Our Planet, July 12-15, Vancouver, Canada. https://doi.org/10.13140/2.1.1886.1120.

Menon, R., Tiwari, A., Chhabra, A., \& Singh, D. (2014). Study on the higher education in India and the need for a paradigm shift. Procedia Economics and Finance, 2(1), 886-871. https://doi.org/10.1016/S22125671(14)00250-0.

Metag, J., \& Marcinkowski, F. (2013). Technophobia towards emerging technologies? A comparative analysis of the media coverage of nanotechnology in Austria, Switzerland and Germany. Journalism: Theory, Practice \& Criticism, 15(4), 463-481. https://doi.org/10.1177/1464884913491045.

Molina-Castillo, F.-J., Lopez-Nicolas, C., \& de Reuver, M. (2020). Mobile payment: The hiding impact of learning costs on user intentions. Journal of Theoretical and Applied Electronic Commerce Research, 15(1). https://doi.org/10.4067/s0718-18762020000100102.

Mulatu, A., Anbessa, A., Misra, S., Adewumi, A., Damaševičius, R., \& Ahuja, R. (2018), Hybrid Mobile learning architecture for higher education, in towards extensible and adaptable methods in computing (pp. 373-383). doi:https://doi.org/10.1007/978-981-13-2348-5_28. 
Nikolopoulou, K. (2020). Secondary education teachers' perceptions of mobile phone and tablet use in classrooms: Benefits, constraints and concerns. Journal of Computers in Education, 1-19. https://doi. org/10.1007/s40692-020-00156-7.

Noh, Y. (2016). A study on the effect of digital literacy on information use behavior. Journal of Librarianship and Information Science, 49(1), 26-56. https://doi.org/10.1177/0961000615624527.

Ojino, R., \& Mich, L. (2018). Mobile applications in university education: The case of Kenya. Journal of ELearning and Knowledge Society, 14(1), 111-125. https://doi.org/10.20368/1971-8829/1369.

Oliemat, E., Ihmeideh, F., \& Alkhawaldeh, M. (2018). The use of touch-screen tablets in early childhood: Children's knowledge, skills, and attitudes towards tablet technology. Children and Youth Services Review, 88, 591-597. https://doi.org/10.1016/j.childyouth.2018.03.028.

Papadakis, S., Kalogiannakis, M., \& Zaranis, N. (2017). Designing and creating an educational app rubric for preschool teachers. Education and Information Technologies, 22(6), 3147-3165. https://doi.org/10.1007 /s10639-017-9579-0.

Phua, P. L., Wong, S. L., \& Abu, R. (2012). Factors influencing the Behavioural intention to use the internet as a teaching-learning tool in home economics. Procedia - Social and Behavioral Sciences, 59, 180-187. https://doi.org/10.1016/j.sbspro.2012.09.263.

Pramana, E. (2018). Determinants of the adoption of mobile learning systems among university students in Indonesia. Journal of Information Technology Education: Research, 17, 365-398. https://doi. org/10.28945/4119.

Pynoo, B., Devolder, P., Tondeur, J., Van Braak, J., Duyck, W., \& Duyck, P. (2011). Predicting secondary school teachers' acceptance and use of a digital learning environment: A cross-sectional study. Computers in Human Behaviour, 27(1), 568-575. https://doi.org/10.1016/j.chb.2010.10.005.

Raziunaite, P., Miliunaite, A., Maskeliunas, R., Damasevicius, R., Sidekerskiene, T., \& Narkeviciene, B. (2018), Designing an educational music game for digital game based learning: A Lithuanian case study, in 41 st international convention on information and communication technology, electronics and microelectronics (MIPRO). Doi:https://doi.org/10.23919/mipro.2018.8400148.

Remmik, M. and Karm, M. (2012), Novice university teachers' professional learning: To follow traditions or change them?, Studies for the Learning Society, Vol. 12 no 2/3 pp. 121-131. DOI https://doi.org/10.2478 /v10240-012-0011-4.

Ross, W., \& LaCroix, J. (1996). Multiple meanings of trust in negotiation theory and research: A literature review and integrative model. International Journal of Conflict Management, 7(4), 314-360. https://doi. org/10.1108/eb022786.

Salemink, K., Strijker, D., \& Bosworth, G. (2017). Rural development in the digital age: a systematic literature review on unequal ICT availability, adoption, and use in rural areas. Journal of Rural Studies, 54, 360371. https://doi.org/10.1016/j.jrurstud.2015.09.001.

Sathye, S., Prasad, B., Sharma, D., Sharma, P., \& Sathye, M. (2018). Factors influencing the intention to use of mobile value-added services by women-owned microenterprises in Fiji. The Electronic Journal of Information Systems in Developing Countries, 84(2), e12016. https://doi.org/10.1002/isd2.12016.

Segars, A. H., \& Grover, V. (1993). Re-examining perceived ease of use and usefulness: A confirmatory factor analysis. MIS Quarterly, 17(4), 517-525. https://doi.org/10.2307/249590.

Sharkins, K. A., Newton, A. B., Albaiz, N. E. A., \& Ernest, J. M. (2015). Preschool children's exposure to media, technology, and screen time: perspectives of caregivers from three early childcare settings. Early Childhood Education Journal, 44(5), 437-444. https://doi.org/10.1007/s10643-015-0732-3.

Sharma, S., Mukherjee, S., Kumar, A., \& Dillon, W. R. (2005). A simulation study to investigate the use of cutoff values for assessing model fit in covariance structure models. Journal of Business Research, 58(7), 935-943. https://doi.org/10.1016/j.jbusres.2003.10.007.

Shukla, A., \& Sharma, S. K. (2018). Evaluating consumers' adoption of Mobile Technology for Grocery Shopping: An application of technology acceptance model. Vision: The Journal of Business Perspective, 22(2), 185-198. https://doi.org/10.1177/0972262918766136.

Singh, H., \& Miah, S. J. (2020). Smart education literature: A theoretical analysis. Education and Information Technologies, 1-30. https://doi.org/10.1007/s10639-020-10116-4.

Steiger, J. H. (2007). Understanding the limitations of global fit assessment in structural equation modeling. Journal of Personality and Individual Differences, 42(5), 893-898. https://doi.org/10.1016/j. paid.2006.09.017.

Štuikys, V., Burbaite, R., Blažauskas, T., Barisas, D., \& Binkis, M. (2017). Model for introducing STEM1 into high school computer science education. International Journal of Engineering Education, 33(5), 1684-1698.

Tankeleviciene, L., \& Damaševičius, R. (2009a). Characteristics of domain ontologies for web based learning and their application for quality evaluation. Informatics in Education, 8(1), 131-152. 
Tankelevičiene, L., \& Damaševičius, R. (2009b). Towards a conceptual model of learning context in elearning. In 9th IEEE international conference on advanced learning technologies, ICALT 2009 (pp. 645646). https://doi.org/10.1109/ICALT.2009.184.

Torkar, G., Avsec, S., Čepič, M., Savec, V. F., \& Juriševič, M. (2018). Science and technology education in Slovenian compulsory basic school: Possibilities for gifted education. Roeper Review, 40(2), 139-150. https://doi.org/10.1080/02783193.2018.1434710.

Tsang, S., Royse, C. F., \& Terkawi, A. S. (2017). Guidelines for developing, translating, and validating a questionnaire in perioperative and pain medicine. Saudi Journal of Anaesthesia, 11(Suppl 1), S80-S89. https://doi.org/10.4103/sja.SJA 20317.

Urbach, N., \& Ahlemann, F. (2011). Structural equation Modelling in information system research using partial least squares. Journal of Information Technology, Theory and Applications, 11(2), 5-40.

Venkatesh, V., Morris, M. G., Davis, G. B., \& Davis, F. D. (2003). User acceptance of information technology: Toward a unified view. MIS Quarterly, 27(3), 425-478. https://doi.org/10.2307/30036540.

Venkatesh, V., Thong, J., \& Ku, K. (2012). Consumer acceptance and use of information technology: Extending the unified theory of acceptance and use of technology. MIS Quarterly, 36(1), 157-178. https://doi.org/10.2307/41410412.

Wang, X., \& Wong, B. (2019). Bridging knowledge divides utilizing cloud computing learning resources in underfunded schools: Investigating the determinants. Journal of Educational Computing Research, 57(3), 591-617. https://doi.org/10.1177/0735633118759455.

Wogu, I. A. P., Misra, S., Assibong, P. A., Olu-Owolabi, E. F., Maskeliūnas, R., \& Damasevicius, R. (2019). Artificial intelligence, smart classrooms and online education in the 21 st century. Journal of Cases on Information Technology, 21(3), 66-79. https://doi.org/10.4018/jcit.2019070105.

Xie, A. (2017) Analysis of the virtual learning community user adoption behavior based on perceived risk. Biomedical Research Volume 28, Issue 9.

Zaranis, N. (2016). The use of ICT in kindergarten for teaching addition based on realistic mathematics education. Education and Information Technologies, 21(3), 589-606. https://doi.org/10.1007/s10639-014-9342-8.

Zaranis, N., Kalogiannakis, M., \& Papadakis, St. (2013). Using mobile devices for teaching realistic mathematics in kindergarten education. Creative Education, 4(7A1), 1-10.

Zhang, W., \& Guterrez, O. (2007). Information technology acceptance in the social services sector context: An exploration. Social Work, 52(3), 221-231. https://doi.org/10.1093/sw/52.3.221.

Zhang, X., \& Maruping, I. (2008). Household technology adoption in a global marketplace: Incorporating the role of espoused cultural values. Information Systems Frontiers, 10(4), 403-413. https://doi.org/10.1007 /s10796-008-9099-y.

Publisher's note Springer Nature remains neutral with regard to jurisdictional claims in published maps and institutional affiliations.

\section{Affiliations}

\section{Sheshadri Chatterjee ${ }^{1}$ - Dipasree Majumdar ${ }^{2} \cdot$ Sanjay Misra ${ }^{3,4} \cdot$ Robertas $^{2}$ Damaševičius ${ }^{5}$}

Sheshadri Chatterjee

sheshadri.academic@gmail.com

Dipasree Majumdar

dipasree@live.com

1 Indian Institute of Technology Kharagpur, Kharagpur, West Bengal, India

2 Barlow Girls' Institute, North Bengal University, Malda, West Bengal, India

3 Department of Electrical and Information Engineering, Covenant University, Ota, Nigeria

4 Department of Computer Engineering, Atilim University, Ankara, Turkey

5 Faculty of Applied Mathematics, Silesian University of Technology, Kaszubska 23, 44-100 Gliwice, Poland 